\title{
TINDAK TUTUR ILOKUSI PADA PERTUNJUKKAN DRAMA VIRTUAL BERJUDUL MONUMEN KARYA INDRA TRANGGONO
}

\author{
Alfi Khoiru An Nisa \\ Universitas Muhammadiyah Malang \\ Email: alfinisaaaa@gmail.com
}

\begin{abstract}
Abstrak: Dalam suatu tindak tutur minimal terlibat unsur penutur dan mitra tutur yang antara keduanya akan terbangun makna tuturan, salah satunya tuturan ilokusi. Tujuan penelitian ini adalah untuk mendeskripsikan bentuk atau jenis tindak tutur ilokusi yang ada pada dialog setiap tokoh pada video karya seni pertunjukkan drama virtual yang dituliskan oleh Indra Tranggono yang berjudul Monumen yang dibawakan oleh Teater Kandang. Penelitian ini termasuk penelitian kualitatif dengan pendekatan deksriptif. Sumber data yang digunakan dalam bentuk video karya seni pertunjukkan yang diunduh di Youtube. Data yang digunakan adalah kutipan berupa kalimat atau dialog pada tokoh. Penelitian ini menggunakan teknik pengumpulan data berupa pengunduhan video di Youtube Lab Drama UMM yang kemudian dilanjut dilakukan transkripsi tuturan pada setiap adegan, kemudian dikelompokkan sesuai dengan indikator penelitian tindak tutur ilokusi. Hasil penelitian menunjukkan bahwa tindak tutur ilokusi terdapat lima jenis: (1) tindak tutur asertif, berupa menyatakan, mengeluh, melaporkan, dan menunjukkan; (2) tidak tutur direktif, berupa jenis tindak tutur menyuruh, mengajak, meminta, menyarankan, menasihati, dan menantang; (3) tindak tutur komisif, berupa berjanji, menawarkan sesuatu, dan mengancam; (4) tindak tutur ekspresif berupa menyalahkan, memuji, dan menyanjung; dan (5) tindak tutur deklaratif berupa tindak tutur memutuskan dan melarang. Dapat disimpulkan bahwa ada lima jenis tindak tutur ilokusi dalam pertunjukan drama virtual berjudul Monumen, yaitu asertif, direktif, komisif, ekspresif, dan deklaratif.
\end{abstract}

Kata Kunci: tindak tutur ilokusi, karya seni pertujukkan, tindak tutur tokoh, drama virtual

\section{ILOCUTION SPEAKING ACTION ON VIRTUAL DRAMA SHOW TITLED MONUMEN BY INDRA TRANGGONO}

\begin{abstract}
In a speech act minimally involved elements of the speaker and speech partner between the two of which the meaning of the speech will be built, one of which is illocutionary speech.This study aims research is to describe the form or type of illocutionary speech act that is in the dialogue of each character in the video of a virtual drama performance art written by Indra Tranggono entitled Monument by Teater Kandang. This research is a qualitative research with a descriptive approach. The source of the data used is in the form of videos of performing arts that are downloaded on Youtube. The data used are quotes in the form of sentences or dialogues on the characters. This study uses data collection techniques in the form of downloading videos on Youtube Drama Lab UMM which is then followed by transcription of speech in each scene, then grouped according to the research indicators of illocutionary speech acts. The results showed that there are five types of illocutionary speech acts: (1) assertive speech acts, in the form of stating, complaining, reporting, and showing; (2) not directive speech, in the form of speech acts of ordering, inviting,
\end{abstract}

BASASTRA Jurnal Bahasa, Sastra, dan Pengajarannya

Volume 9 Nomor 2, Oktober 2021, P-ISSN 2302-6405, E-ISSN 2714-9765 
asking, suggesting, advising, and challenging; (3) commissive speech acts, in the form of promising, offering something, and threatening; (4) expressive speech acts in the form of blaming, praising, and flattering; and (5) declarative speech acts in the form of deciding and forbidding speech acts. It can be concluded that there are five types of illocutionary speech acts in a virtual drama show entitled Monument, namely assertive, directive, commissive, expressive, and declarative

Keywords: ilocution speaking, art show, character's speech, virtual drama

\section{PENDAHULUAN}

Bahasa merupakan salah satu sarana yang digunakan oleh masyarakat untuk berkomunikasi satu sama lain, bahasa menjadi elemen paling penting dalam bermasyarakat atau bersosial karena dengan bahasa seseorang dapat memahami apa yang sedang diinginkan oleh orang lain. Bahasa juga biasa disebut arbitrer, karena bahasa digunakan sesuai dengan kesepakatan kelompok atau masyarakat yang menggunakan bahasa tersebut. Dalam pelafalan atau pengucapan bahasa terdapat tindak tutur di dalamnya.

Tindak tutur menurut Apriastuti (2017) tindak tutur adalah seluruh tindakan untuk mengekspresikan seluruh pikiran dan perasaan yang dilakukan oleh seseorang dengan bentuk realisasi berbicara. Sedangkan menurut Qomariyah berpendapat bahwa tindak tutur adalah tuturan yang terdapat suatu tindakan, ujaran, penutur memiliki sesuatu yang ingin didapat atau dihasilkan dari mitra tutur. Dari penjelasan di atas dapat disimpulkan bahwa tindak tutur adalah tuturan atau ujaran yang diujarkan oleh penutur untuk mendapatkan sesuatu dari mitra tutur. Tindak tutur sendiri terbagi menjadi 3 jenis yaitu tindak tutur lokusi, tindak tutur ilokusi dan tindak tutur perlokusi (Rahma, 2018).

Penelitian ini difokuskan pada tindak tutur ilokusi, tindak tutur ilokusi menurut Megawati (2016) adalah suatu tindakan yang dilakukan oleh penutur dalam mengatakan sesuatu, sebagai tujuan atau makna dari suatu ujaran misalnya membuat perjanjian, pernyataan, perintah atau permintaan. Pendapat lain datang dari Yuliana dkk. (2013) tindak tutur ilokusi adalah tindak tutur yang memiliki tujuan dan manfaat tertentu, tindak tutur lokusi adalah tindak tutur yang sesuai dengan makna yang terucap. Dari kedua pendapat di atas dapat disimpulkan bahwa seluruh tuturan yang memiliki makna asli yang terfokus pada perintah, permintaan dsb merupakan dari tindak tutur ilokusi

Tindak tutur ilokusi juga masih terbagi menjadi beberapa bagian yaitu tindak tutur ilokusi asertif, tidak tutur ilokusi ekspresif, tindak tutur ilokusi direktif, tidak tutur ilokusi komisif, dan tindak tutur ilokusi deklarasi (Fatonah dkk., 2018).

Asertif menurut Arifiany (2016) yaitu tuturan yang terikat pada penutur dengan kebenaran proposisi, sependapat dengan sebelumnya Praptiwi (2020) mengatakan bahwa 
asertif adalah ujaran yang dikatakan oleh penutur yang terikat dengan kebenaran proposisinya. Terdapat pendapat lain dari tindak tutur asertif adalah tindak tutur yang megikat penuturnya untuk selalu melakukan kebenaran atas perkataannya. Dari ketiga pendapat di atas dapat disimpulkan bahwa tindak tutur asertif berisikan proposisi yang mengikat penuturnya untuk melakukan apa yang dikatakan.

Tindak tutur asertif menurut Arifiany dan Ratna (2016) berisikan berisi tentang menyatakan, menyarankan, membual, mengeluh dan mengklaim. Pendapat lain datang dari Praptiwi (2020) asertif terdiri dari menyatakan, mengusulkan, membual, mengemukakan pendapat, melaporkan, mengeluh dan menunjukkan. Dari kedua pendapat di atas dapat disimpulkan bahwa isi dari tindak tutur asertif berupa, menyatakan, menyarankan, membual, mengeluh, mengklaim, melaporkan, menunjukkan dan megemukakan pendapat.

Tindak tutur direktif menurut Qomariyah (2017) adalah salah satu dari tindak tutur yang digunakan oleh penutur untuk meminta atau menyuruh orang lain atau mitra tutur untuk melakukan sesuatu hal yang menjadi keinginan penutur, hal tersebut dapat bermanfaat bagi penutur pribadi dan juga bisa bermanfaat bagi mitra tutur. Sepedapat dengan Qomariyah, Elmita dkk (2013) mengatakan bahwa tindak tutur direktif adalah tindak tutur yang dilakukan oleh penutur dengan memiliki tujuan agar mitra tutur melakukan tindakan yang telah dituturkan oleh penutur sebelumnya. Pendapat Arifiany dan Ratna (2016) bahwa direktif adalah tuturan yang dimaksudkan untuk membuat pengaruh agar mitra tutur melakukan tindakan, seperti memerintah, dan memohon. Dari beberapa pendapat di atas dapat ditarik benang merah mengenai tindak tutur direktif adalah ujaran atau tuturan yang dituturkan oleh penutur kepada mitra tutur dengan maksud tertentu, maksud tersebut berbentuk permintaan atau permohonan dari penutur kepada mitra tutur agar melakukan hal yang diujarkan sebelumnya.

Tindak tutur direktif terbagi menjadi beberapa jenis, yaitu berdasarkan pendapat dari Stambo dan Ramadhan (2019) menyebutkan 7 jenis tindak tutur direktif yaitu menyuruh, mengajak, meminta, memohon, menyarankan, mengimbau, dan menasihati. Berseberangan dengan pendapat Stambo, Ramadhan, Elmita dkk. (2013) hanya menyebutkan 5 jenis tindak tutur direktif yaitu: menyuruh, memohon, menyarankan, menasihati dan menantang. Pendapat ketiga datang dari Sagita dan Setiawan (2020) mengatakan jenis tindak tutur direktif meliputi nasihat, perintah, pertanyaan, permintaan, penawaran, dan pemesanan. Dari ketiga jenis di atas dapat disimpulkan bahwa jenis tindak tutur direktif meliputi menyuruh, mengajak, meminta, memohon, 
menyarankan, mengimbau, menasihati, menantang, menawar dan memesan.

Tindak tutur komisif adalah tindak tutur yang mengutarakan janji atau penawaran (Arifiany \& Ratna, 2016). Pendapat lain datang dari Praptiwi (2020) mengatakan tindak tutur komisif adalah tindak tutur yang mengikat penuturnya di masa depan. Dan juga Elmita dkk. (2013) tindak tutur komisif adalah tindak tutur yang mengikat penuturnya yang akan dilaksakan apa yang dituturkan sebelumnya. Dari ketiga pendapat di atas dapat ditarik benang merah berupa tindak tutur komisif adalah segala tindak tutur yang berisikan pengikat bagi penutur yang kelak akan dilaksanakan baik dalam jangka waktu dekat ataupun waktu yang panjang.

Tindak tutur komisif berisikan beberapa makna menurut pendapat dari Elmita dkk. (2013) mengatakan bahwa komisif berisi tentang berjanji, bersumpah dan mengancam. Sejalan dengan pendapat sebelumnya Wahyuni dkk. (2018) mengemukakan hanya terdapat dua makna yaitu perjanjian dan penawaran. Pendapat lain juga datang dari Suryatin (2018) jenis dari komisif terdapat tiga yaitu berjanji, bersumpah dan menawarkan sesuatu. Dari ketiga pendapat di atas dapat disimpulkan bahwa jenis dari komisif yaitu berjanji, bersumpah, menawarkan sesuatu dan mengancam.

Tindak tutur ekpresif adalah tindak tutur yang memilki fungsi menyatakan atau menunjukkan sikap psikologis penutur dalam suatu keadaan (Suryatin, 2018). Sejalan dengan pendapat sebelumnya Nurinna (2016) berpendapat tindak tutur ekspresif adalah tindak tutur yang menunjukkan sikap psikologis seorang penutur. Dari kedua pendapat di atas dapat disimpulkan bahwa tindak tutur ekspresif adalah suatu tuturan yang melambangkan sikap psikologis dari penutur.

Jenis dari tindak tutur ekspresif menurut Suryatin (2018) berisi tentang berterima kasih, memberi selamat, meminta maaf, menyalahkan, memuji dan berbela sungkawa. Pendapat lain yang dikemukakan Siddiq (2019) mengatakan bahwa isi dari tindak tutur ekspresif adalah mengucapkan terima kasih, mengucapkan selamat, menyanjung, dan memuji. Dengan demikian tindak tutur ekspresif memiliki beberapa jenis yaitu tuturan yang berisi permintaan maaf, berterima kasih, pengucapan selamat, menyalahkan, berbela sungkawa, memuji, dan menyanjung.

Tindak tutur deklaratif adalah tindak tutur yang berisikan pengaruh dan pengubah keadaan tertentu yang terjadi pada saat kejadian (Sagita \& Setiawan, 2020). Sedangkan Stambo dan Ramadhan (2019) mengatakan tindak tutur deklaratif adalah tindak tutur yang dilakukan dengan maksud menciptakan suasana baru. Dan pendapat lain datang dari Purba (2011) mengatakan bahwa tindak tutur deklaratif adalah tindak tutur yang 
menggambarkan suatu perubahan dalam keadaan hubungan. Dari ketiga penjelasan di atas dapat disimpulkan bahwa tindak tutur deklaratif adalah tuturan yang diucapkan oleh penutur untuk merubah keadaan tertentu.

Jenis tindak tutur deklaratif menurut Sagita dan Setiawan (2020) yaitu membaptis, memecat, menjatuhkan hukuman dan menominasikan calon. Purba (2011) mengatakan jenis dari tindak tutur deklaratif adalah memundurkan diri. Dan pendapat lain datang dari Stambo dan Ramadhan (2019) mengatakan jenis dari tindak tutur deklaratif adalah memutuskan, membatalkan, melarang, dan mengizinkan. Dapat disatukan dari ketiga pendapat di atas bahwa jenis dari tindak tutur deklaratif yaitu, membaptis, memecat, menjatuhkan hukuman, menominasikan calon, memundurkan diri, memutuskan, membatalkan, melarang dan mengizinkan.

Dari paparan sebelumnya mengenai pengertian maupun jenis dari tindak tutur ilokusi maka terdapat keinginan untuk meneliti mengenai bahasa lisan yang digunakan oleh para aktor yang terdapat pada karya seni pertujukkan dengan adopsi dari naskah Monumen karya Indra Tranggono yang dimainkan atau diperankan oleh Teater Kandang. Dengan demikian penelitian ini memiliki titik fokus pada tindak tutur ilokusi yang ada pada dialog setiap tokoh yang ada pada video yang diunggah di akun Youtube Lab Drama UMM pada bulan Juli tahun 2021.

Penelitian mengenai tindak tutur ilokusi bukan kali pertama dilakukan, akan tetapi ada penelitian terdahulu. Pada penelitian sebelumnya yang dilakukan oleh Sagita dan Setiawan (2020) meneliti tentang Tindak Tutur Ilokusi Ridwan Kamil dalam Talkshow Insight di CNN Indonesia, hasil penelitiannya berupa temuan tindak tutur yang digunakan oleh Ridwan Kamil berupa Pertama, bentuk tindak tutur ilokusi yang ditemukan berupa deklaratif, imperatif, dan interogatif. Kedua, jenis tindak tutur ilokusi yang ditemukan berupa asertif, direktif, komisif, dan ekspresif. Perbedaan penelitian yang dilakukan oleh Sagita dan Setiawan dengan penelitian yang akan dilakukan adalah objek penelitian yang berbeda, dan juga konteks yang ada pada objek berbeda, pada penelitian Sagita dan Setiawan dilakukan pada penutur yang dilakukan dengan tidak sengaja, sedangkan objek penelitian ini dialog sudah dirancang pada sebelumnya.

Penelitian lain juga dilakukan oleh Praptiwi (2020) meneliti tentang Tindak Tutur Ilokusi Guru Pada Kegiatan Belajar Mengajar di SMP Labschool Unesa Ketintang Surabaya dengan hasil penelitian berupa tindak tutur ilokusi memiliki maksud yaitu memerintah, menuntut, dan memesan. Selain direktif, ada tindak ilokusi asertif, komisif, ekspresif, dan deklaratif. Perbedaan penelitian yang

BASASTRA Jurnal Bahasa, Sastra, dan Pengajarannya 
dilakukan oleh Praptiwi dengan penelitian yang akan dilakukan adalah dalam objek, objek yang digunakan adalah siswa atau pelajar SMP sedangkan penelitian yang akan dilakukan menggunakan objek tokoh atau aktor yang sedang melakukan pengadeganan. Pebedaannya adalah tindak tutur yang keluar disengaja dan tidak disengaja.

Dari penelitan terdahulu di atas maka dapat disimpulkan bahwa penelitian ini perlu dilakukan karena penelitian tindak tutur ilokusi pada pengadeganan atau pada tindak tutur yang disengaja belum banyak yang meneliti sehingga dengan itu penelitian ini perlu dilakukan mengingat penelitian dengan objek pentas seni drama virtual baru kali pertama dilakukan. Penelitian ini memiliki tujuan untuk mendeskripsikan tindak tutur ilokusi yang ada pada dialog setiap tokoh yang sedang melakukan pengadeganan menggunakan naskah drama dari Indra Tranggono yang berjudul Monumen.

\section{METODE}

Pendekatan yang digunakan dalam penelitian ini adalah pendekatan deskriptif kualitatif. Menurut Fadli (2021) tujuan dari penelitian kualitatif adalah mengetahui kebenaran fenomena yang terjadi pada masyarakat yang kemudian tersaji dengan gambaran yang lengkap serta terperinci dengan data yang digunakan menggunakan informan yang dapat dipercaya yang kemudian terjadi secara alamiah. Dari penjelasan di atas dapat disimpulkan bahwa penelitian kualitatif digunakan untuk terfokus pada fenomena tindak tutur ilokusi yang ada data, yang kemudian dituliskan dengan deskriptif berupa uraian mengenai fenomena yang ditemukan.

Sumber data yang digunakan adalah kalimat atau dialog yang diucapkan oleh para tokoh yang sedang melalukan pengadeganan yang diunduh di laman Youtube Lab Drama. Data yang digunakan dalam penelitian ini yaitu setiap kalimat atau dialog yang masih relevan dengan teori tindak tutur ilokusi. Dan kemudian dilakukan teknik pengumpulan data berupa pengunduhan video di laman Youtube Lab Drama UMM, kemudian membuat transkripsi setiap dialog antartokoh, yang kemudian dikelompokkan sesuai dengan teori dari tindak tutur ilokusi yang sesuai dengan indikator penelitian tindak tutur ilokusi. Hasil temuan berupa kalimat atau dialog dilakukan analisis dalam bentuk deskripsi sesuai denggan teori yang sudah ada dan selanjutnya hasil yang sudah dideskripsikan dilakukan penarikan kesimpulan dan dijadikan sebagai artikel penelitian.

\section{HASIL DAN PEMBAHASAN}

Tujuan dari penelitian ini adalah untuk mendeskripsikan tindak tutur ilokusi dari pentas seni pertunjukan drama virtual yang 
dilakukan oleh Teater Kandang dengan menggunakan naskah yang ditulis oleh Indra Tranggono yang berjudul Monumen. Hasil penelitian dengan rincian berikut:

Tindak Tutur Asertif dalam Karya Seni Pertunjukkan Drama

Jenis tindak tutur ilokusi yang pertama yaitu asertif, tindak tutur asertif adalah tindak tutur yang mengikat penuturnya untuk menuturkan kebenaran dari setiap tuturannya.

\section{Tindak Tutur Asertif Menyatakan}

Tindak tutur asertif juga memiliki beberapa jenis, jenis yang pertama adalah menyatakan.

Durmo: Kurang ajar. Kita dianggap dhemit

Data pertama datang dari dialog yang diucapkan oleh salah satu tokoh monumen atau patung yang bernama Durmo, pada kesempatan ini Durmo menyatakan kekesalannya terhadap apa yang dilakukan oleh manusia yang sedang membaca mantra di hadapannya sehingga membuat Durmo kesal dan memaki manusia tersebut, meskipun Durmo tahu kalau dia tidak dapat didengar oleh manusia tersebut, dia hanya mampu menyatakan kepada teman monumen. Dia menyatakan kepada teman monumen bahwa dia dan teman-temannya dianggap demit, demit merupakan bentuk bahasa tidak baku dari dedemit yang berarti makhluk halus yang suka mengganggu atau dapat juga dianggap roh jahat yang dapat membantu manusia dalam melakukan hal-hal yang tidak wajar yang diinginkan oleh manusia, baik ataupun buruk.

Data di atas dikatakan sebagai data dari tindak tutur asertif menyatakan karena pada dialog Durmo yang sedang menyatakan atau menerangkan bahwa dirinya dan teman monumen dianggap demit oleh manusia yang sedang membaca mantra sebelumnya.

Yu Seblak: tapi saya ndak takot Data kedua dari tindak tutur asertif menyatakan datang dari dialog manusia yang bernama Yu Seblak, dialog ini terjadi karena pada saat itu manusia yang bernama Yu Seblak sedang diancam oleh petugas untuk mengatakan di mana pencopet yang sedang dicari oleh petugas tersebut. akan tetapi $\mathrm{Yu}$ Seblak merasa tidak takut dengan ancaman tersebut karena mungkin ancaman tersebut sudah biasa dia terima dari beberapa orang lainnya sehingga dengan demikian Yu Seblak menyatakan bahwa dirinya tidak takut. Data di atas merupakan bahasa lisan karena terdapat bahasa tidak baku di dalamnya frasa "ndak takot" merupakan frasa tidak baku, bentuk baku yang benar adalah "tidak takut", akan tetapi hal ini tidak menjadi suatu kesalahan karena yang digunakan dalam proses dialog lisan.

Data di atas dikatakan sebagai data tindak tutur asertif menyatakan karena pada dialog tersebut Yu Seblak 
menyatakan atau membuat nyata bahwa dirinya tidak takut akan ancaman yang diberikan oleh lawan mainnya yaitu petugas.

Karep: ya begitulah Ajengku sayang, ternyata mas ini masih menyimpan sedikit bakat sebagai penyair

Data selanjutnya, data ketiga tentang tindak tutur asertif menyatakan datang dari tokoh manusia yang bernama Karep, pada dialog ini Karep sedang bermain peran dengan Ajeng, dia menyatakan kepada Ajeng bahwa dirinya mempunyai bakat sebagai penyair. Dialog ini dikatakan oleh Karep karena pada sebelumnya Ajeng memuji Karep akan kalimat yang puitis yang dia katakan kepada Ajeng sebelumnya.

Data di atas dikatakan data tindak tutur asertif menyatakan karena pada dialog ini Karep menyatakan atau menjelaskan bahwa dirinya masih menyimpan sedikit bakat sebagai penyair.

Cempluk: kita telah dibunuh untuk kedua kalinya

Data terakhir dari tindak tutur asertif menyatakan datang dari dialog Cempluk salah satu dari monumen, pada dialog ini Cempluk menyatakan dirinya telah dibunuh untuk kedua kalinya, dialog ini terucap karena Cempluk aslinya sudah meninggal yang kemudian rakyat memiliki inisiatif untuk membangun monumen untuknya. Akan tetapi, pada hari itu ia merasa dibunuh untuk kedua kalinya karena dia akan digusur menggunakan buldoser oleh para rakyat di masa itu sehingga dengan kejadian itu Cempluk menyatakan atau membuat nyata bahwa dirinya telah dibunuh untuk kedua kalinya.

\section{Tindak Tutur Asertif Mengeluh}

Jenis tindak tutur asertif yang kedua yaitu mengeluh, tindak tutur mengeluh adalah tindak tutur yang dituturkan oleh penutur dengan kenyataan sedang susah bisa saja karena suatu penderitaan, kesakitan, kekecewaan yang sedang dialami oleh penutur.

Durmo: tapi kenapa wajahku ini tetap saja dibuat bopeng mestinya kan mereka bisa membuat wajahku sedikiti lebih tampan.

Data di atas merupakan data tindak tutur asertif mengeluh. Dialog yang disampaikan oleh monumen yang bernama Durmo, ia berbicara menanyakan kepada rekan-rekannya kenapa wajahnya ketika dijadikan patung tetap dibiarkan ada bopengnya, dia ingin wajahnya dipoles dengan lebih tampan karena dia merasa tidak percaya diri akan bentuk monumennya. Tokoh Durmo merasa susah dan mengeluh karena kekecewaan bentuk monumen dirinya sehingga muncul dialog berupa keluhan atas dirinya yang ia rasa tidak sama dengan teman monumen yang lain.

Data di atas disebut dengan data tindak tutur asertif mengeluh karena 
makna yang disampaikan dari dialog Durmo berisikan keluhan karena kekecewaan dirinya atas bentuk monumen yang dibuat.

\section{Tindak Tutur Asertif Melaporkan}

Jenis tindak tutur asertif ketiga yaitu melaporkan. Tindak tutur ini berisikan laporan yang diberikan penutur kepada mitra tutur.

Kalur: Tolong Yu, rekanrekanku di markas juga sudah diangkut oleh petugas $Y u$

Data di atas merupakan data dari tindak tutur melaporakn yang dilakukan oleh tokoh manusia yang bernama Kalur, dia sedang memberikan laporan kepada $\mathrm{Yu}$ Seblak, bahwa rekan-rekan yang tadinya ada di markas, pada saat itu sudah tidak ada lagi karena sudah diangkut oleh para petugas. Data ini masuk dalam malaporkan karena berita yang disampaikan oleh Kalur sebelumnya belum diketahui oleh Yu Seblak.

\section{Tindak Tutur Asertif Menunjukkan}

Jenis keempat dari tindak tutur asertif adalah menunjukkan. Tindak tutur menunjukkan bisa berisi mengenai memperlihatkan sesuatu, menyatakan sesuatu atau juga bisa menerangkan dengan diperkuat oleh bukti. Dengan penjelasan data di bawah ini:

Ratri: Nah...kalian lihat di sana. Deretan rumah-rumah mewah yang menyimpan jutaan keluarga bahagia. Ada kolam renang pribadi, lapangan golf pribadi, mobil mewah bahkan pesawat terbang pribadi

Data di atas merupakan data dari tindak tutur asertif menunjukkan yang terdapat dari dialog monumen yang bernama Ratri. Pada saat ituu Ratri sedang menunjukkan sesuatu kepada rekan monumen dengan menerangkan sambil menunjuk bukti berupa rumah yang mewah di sudut kanan mereka. Data ini valid termasuk ke dalam tindak tutur menunjukkan karena penutur atau Ratri sedang memperlihatkan sesuatu dengan ditambah bukti yaitu rumah-rumah mewah yang terdapat di samping kanan mereka.

\section{Tindak Tutur Direktif dalam Karya Seni Pertunjukkan Drama}

Jenis tindak tutur kedua adalah tindak tutur direktif, tindak tutur direktif adalah tindak tutur yang dituturkan oleh penutur berupa permintaan atau permohonan agar mitra tutur melakukan apa yang dituturkan oleh penutur tersebut. Tindak tutur direktif juga masih terbagi menjadi beberapa jenis yaitu dengan rincian penjelasan menggunakan data di bawah ini:

\section{Tindak Tutur Direktif Menyuruh}

Tindak Tutur pertama dari jenis direktif adalah menyuruh. Tindak tutur menyuruh berisi kalimat yang memiliki makna suruhan dari penutur kepada 
mitra tutur agar mitra tutur mau melakukan yang disuruh oleh penutur.

Yu Seblak : mau apa datang ke sini, langsung bilang

Data pertama datang dari dialog yang diucapkan oleh tokoh manusia yang bernama Yu Seblak, pada saat itu dia kedatangan tamu seorang koruptor, akan tetapi koruptor tersebut belum mengatakkan apa yang dia inginkan atau belum menjelaskan maksud kedatangannya ke Yu Seblak, sehingga muncul tuturan dari Yu Seblak, berupa suruhan agar koruptor mengatakan apa maksud kedatangannya dengan kata kunci kalimat [langsung bilang]. Dari data di atas jelas bahwa Yu Seblak menyuruh koruptor untuk mengtakan maksud kedatangannya.

Karep: sekarang duduk, diam dan dengarkan!

Data kedua datang dari tokoh Karep, pada saat ia menjelaskan sesuatu kepada kekasihnya Ajeng, mengenai pemugaran yang akan dilakukan pada monumen, menimbulkan ketidakpercayaan dari teman manusia yang lain, sehingga kemudian Karep berkeinginan untuk menjelaskan apa yang terjadi sebenarnya dengan menyuruh rekanrekannya untuk duduk dan mendengarkan berita yang akan dibacakan, dengan tujuan agar rekannya percaya akan apa yang dia katakan.

Data di atas termasuk dari data tindak tutur direktif jenis menyuruh karena isi atau makna dari tuturan di atas berupa perintah yang dituturkan oleh penutur dengan tujuan agar dilakukan oleh mitra tutur, yaitu duduk diam dan dengarkan.

\section{Tindak Tutur Direktif Mengajak}

Jenis tindak tutur direktif kedua adalah mengajak. Tindak tutur mengajak berisikan tentang permintaan agar supaya mitra tutur turut datang dan sebagainya, bisa juga tuturan ini berisikan tenatng agar membangkitkan hati mitra tutur agar melakukan sesuatu yang sebelumnya dikatakan. Dengan penjelasan lebih detail di bawah ini:

Wibagso: ayo lawan mereka lawan mereka!

Data di atas merupakan data dari tindak tutur direktif jenis mengajak, dialog di atas dikeluarkan oleh tokoh bernama Wibagso. Wibagso mengajak rekan monumen untuk melawan para buldoser agar penggusuran monumen tidak terjadi, data di atas termasuk data tindak tutur direktif menyuruh karena ada kata kunci [ayo] makna kata ini bisa berupa ajakan agar mitra tutur memiliki perasaan bangkit dalam hatinya agar melakukan kegiatan tersebut.

\section{Tindak Tutur Direktif Meminta}

Jenis tindak tutur ketiga yaitu meminta, dengan contoh data di bawah ini.

Koruptor: nah, maksud kedatangan saya mau minta perlindungan sama yu Seblak 
agar saya terbebas dari pemeriksaaan

Data di atas merupakan data dari tindak tutur meminta yang merupakan dialog dari koruptor, pada adegan tersebut, koruptor merasa dirinya kesusahan sehingga meminta perlindungan kepada Yu Seblak.

Data di atas mempunyai kata kunci [minta] sehingga dengan jelas bahwa data di atas merupakan data dari tindak tutur direktif meminta.

\section{Tindak Tutur Direktif Menyarankan}

Jenis keempat dari tindak tutur direktif adalah menyarankan, tindak tutur menyarakan berisikan tindak tutur pemberian saran yang dilakukan oleh penutur kepada mitra tutur. Dengan lebih lanjut menggunakan penjelasan di bawah ini:

Wibagso: Tenanglah. Tidak ada jeleknya membikin hati mereka gembira. Anggap saja ini sekedar intermezzo

Data di atas merupakan dialog dari Wibagso, pada adegan tersebut Wibagso sedang memberikan saran kepada rekannya yang bernama Durmo karena Durmo merasa dirinya tidak dihargai sebagai pahlawan. Sehingga muncul saran dari Wibagso, agar Durmo tetap tenang, dan mengatakan kepada Durmo agar ini dijadikan sebagai intermeso saja. Data di atas masuk ke dalam data menyarankan karena yang penutur tuturkan memiliki manfaat bagi mitra tutur, selain membuat mitra tutur tenang, saran ini juga tidak membuat kegaduhan pada sesama monumen.

\section{Tindak Tutur Direktif Menasihati}

Jenis kelima dari tindak tutur direktif adalah menasihati. Menasihati adalah tuturan yang akan diujarkan oleh penutur berupa pemberian nasihat atau menganjukan sesuatu kepada mitra tutur agar mitra tutur mendapat manfaat untuk pribadinya sendiri.

Kalur: mending kamu jangan ambil uang haram itu, karena uang haram itu tidak akan jadi daging

Data di atas merupakan data dari jenis menasihat. Dialog yang disampaikan oleh Kalur kepada Yu Seblak mengenai uang haram. Kalur mengatakan kepada Yu Seblak bahwa uang haram tidak akan menjadi daging, dan sebaiknya tidak Yu Seblak ambil. Data di atas masuk ke dalam bentuk tuturan menasihati karena apa yang dituturkan Kalur, memiliki manfaat untuk mitra tuturnya yaitu Yu Seblak.

\section{Tindak Tutur Direktif Menantang}

Jenis terakhir atau keenam dari tindak tutur direktif adalah menantang, menantang adalah tindak tutur yang dituturkan oleh penutur yang berisikan tantangan untuk menghadapi atau melawan, berikut rincian dengan data di bawah ini:

Siti: hadapilah wibagso, hadapilah kenapa pahlwan kelas utama takut pada buldoser! 
Data di atas merupakan dialog yang diujarkan oleh Siti, dialog ini ditujukan kepada Wibagso, agar Wibagso mau melawan buldoser, dengan imbuhan mana mungkin pahlawan kelas utama takut kepada buldoser sehingga dengan demikian data ini termasuk ke dalam tindak tutur direktif menantang karena tokoh Siti memberikan tuturan berupa tantangan untuk menghadapi buldoser kepada rekannya yaitu Wibagso.

\section{Tindak Tutur Komisif dalam Karya Seni Pertunjukkan Drama}

Tindak tutur ilokusi yang ketiga adalah tindak tutur komisif, tindak ttutur komisif adalah tindak tutur yang dikeluarkan oleh penutur yang memiliki makna sebuah janji atau penawaran sesuatu kepada mitra tutur. Tindak tutur komisif terbagi menjadi beberapa jenis, sebagai berikut.

\section{Tindak Tutur Komisif Berjanji}

Jenis tindak tutur komisif yang pertama adalah tindak tutur berjanji, tuturan berjanji berisikan tuturan mengucapkan janji atau menyatakan bersedia dalam melakukan suatu hal.

Karep: Ajengku sayang, seandainya kalau ada perubahan kamu akan mas berikan RSS (Rumah Sedikit Semen) kita berdua bisa bercinta di sana mengarungi benua -benua impian

Data di atas merupakan tindak tutur berjanji yang terdapat dalam dialog yang diujarkan oleh Karep, salah satu tokoh manusia yang sedang melakukan adegan dengan kekasihnya yang bernama Ajeng. Pada saat itu Karep mengucapkan jani kepada Ajeng untuk memberikannya RSS (rumah sedikit semen) pada data di atas memang tidak terdapat kata kunci [janji] akan tetapi makna yang tersirat dari data di atas adalah sebuah janji yang diucapkan oleh seorang kekasih demi membahagiakannya. Berjanji adalah penutur mengucapkan kesanggupannya dalam melakukan sesuatu, entah memberi, menolong, dan datang. Dan pada adegan ini Karep bersedia memberikan RSS kepada kekasihnya.

Data di atas dapat disimpulkan merupakan data dari tindak tutur komisif berjanji, karena penutur yang bernama Karep mengucapkan kesediannya untuk memberikan sesuatu kepada mitra tuturnya yang bernama Ajeng.

\section{Tindak Tutur Komisif Menawarkan Sesuatu}

Menawarkan sesuatu adalah jenis kedua dari tindak tutur komisif. Tindak tutur ini berisikan sebuah tawaran yang diberikan oleh penutur kepada mitra tutur dengan rincian data di bawah ini.

Koruptor: Berapapun biaya yang diminta $\mathrm{Yu}$ Seblak dan sesajen yang diminta monumen ini saya siap yu untuk menyiapkan. 
Data di atas merupakan data dari tindak tutur komisif menawarkan sesuatu, dialog di atas dari salah satu tokoh manusia yang tidak diketahui namanya akan tetapi penutur ini dijuluki koruptor, karena telah melakukan korupsi yang kemudian akan dilakukan pemeriksaan sehingga ia mendatangi Yu Seblak untuk meminta perlindungan, karena pada adegan sebelumnya sempat ditolak oleh Yu Seblak, maka koruptor menawarkan sesutau pada Yu Seblak dengan penjelasan dialog di atas. Koruptor menawarkan biaya yang diminta oleh mitra tuturnya akan dituruti berapa pun nominalnya, dan juga ia akan menambahkan biaya untuk biaya sesajen untuk monumen yang menjadi tempat Yu Seblak meminta.

Dapat disimpulkan data di atas merupakan data dari tindak tutur komisif menawarkan sesuatu dengan makna yang terkandung dari dialog di atas bahwa penutur, jelasnya koruptor di atas memberikan penawaran berupa biaya untuk Yu Seblak dan juga sesajen untuk monumen.

\section{Tindak Tutur Komisif Mengancam}

Jenis ketiga dari tindak tutur komisif adalah mengancam. Tindak tutur yang dituturkan oleh penutur berisikan pemberian pertanda atau peringatan terkait kemungkinankemungkinan buruk yang akan terjadi, dengan penjelasan berupa data di bawah ini.
Petugas: Kamu tahu apa ini?

Ini bisa membuatmu mengatakan dimana copet itu berada. Ayo cepat katakan, kalau tidak ini melayang!

Data di atas merupakan data dari tindak tutur komisif mengancam, dialog di atas dituturkan oleh salah satu tokoh manusia, dengan julukan petugas. Petugas ini sedang mencari pencopet yang kemudian ia bertemu dengan Yu Seblak, ketika petugas bertanya kemana pergi pencopet yang sedang ia kejar, Yu Seblak tidak langsung menjawab apa yang ditanyakan oleh petugas, sehingga keluar kalimat ancaman dari petugas. Petugas sebagai penutur telah memberikan peringatan tentang kemungkinan terburuk jika Yu Seblak tidak mengatakan kebenarannya dengan tanda mau melayangkan senjata yang sedang dipegang oleh petugas.

\section{Tindak Tutur Ekspresif dalam Karya Seni Pertunjukkan Drama}

Jenis tindak tutur ilokusi yang keempat adalah ekspresi, tindak tutur ekspresif adalah tindak tutur yang memiliki tujuan menunjukkan sikap atau perlakuan psikologis dari penutur. Tindak tutur ekspresif memiliki beberapa jenis yaitu sebagai berikut:

\section{Tindak Tutur Ekspresif Menyalahkan}

Jenis tindak tutur ekspresif yang pertama adalah menyalahkan. Tindak tutur menyalahkan adalah tindak tutur yang dikeluarkan oleh 
penutur yang penutur anggap atau menyatakan suatu tindakan dari mitra tutur salah.

Wibagso: kenapa kalian malah sinis, padahal kita hendak dihancurkan atas nama laba dan angka-angka

Data pertama datang dari dialog yang dilakukan oleh tokoh monumen yang bernama Wibagso. Pada saat itu Wibagso sedang menyalahkan teman monumen karena pada waktu itu teman-teman monumen tidak pro padanya atau tidak mendukungnya. Sehingga muncul perasaan menyalahkan temannya, di mana Wibagso sebagai penutur dan rekanrekannya menjadi mitra tutur. Data ini dinyatakan sebagai data tindak tutur ekspresif karena intonasi yang keluar dari Wibagso cukup tinggi dan makna yang tersurat dari dialog Wibagso adalah menyalahkan temannya dengan kata kunci pertanyaan "kenapa kalian malah sinis" yang dimaksud Wibagso adalah, setidaknya karena kita akan dihancurkan maka hendaknya kita menjadi satu dan tidak bercerai-berai seperti itu.

Wibagso: Durmo, kenapa nyalimu hendak lumer! Tak sepantasnya pahlwan mengemis seperti itu

Data kedua dari tindak tutur ekspresif menyalahkan juga datang dari tokoh monumen yang bernama Wibagso. Pada babak ini Wibagso hanya menyalahkan rekan monumennya yang bernama Durmo.
Sebelumnya Durmo melakukan permintaan untuk dikasihani, sehingga Wibagso menyalahkan atua menyatakan salah apa yang sebelumnya dilakukan oleh Durmo. Wibagso mengatakan tidak layak seorang pahlawan mengemis kepada manusia yang usianya jauh lebih muda dari mereka. Data di atas benar dikatanya data dari tindak tutur ekspresif menyalahkan denganbukti intonasi yang dikeluarkan oleh Wibagso yang cukup tinggi dan memberikan arahan bahwa tidak sepantasnya rekannya melakukan hal yang sebelumnya dilakukan.

\section{Tindak Tutur Ekspresif Memuji}

Jenis tindak tutur ekspresif yang kedua adalah memuji. Memuji memiliki makna bentuk tuturan yang dituturkan oleh penutur dengan makan kekeaguman atau penghargaan terhadap suatu tindakan dari mitra tutur atau bisa saja pada keadaan.

Yu Seblak: Lur Lur, nasibmu benar-benar mujur yo.

Data pertama dari tindak tutur ekspresif memuji datang dari tokoh manusia yang bernama Yu Seblak. Pada adegan tersebut Yu Seblak sedang berdialog dengan Kalur, yang kemudian Yu Seblak memuji Kalur dan mengganggap nasib dari Kalur yang mujur (beruntung). $\mathrm{Yu}$ Seblak mengatakan ini karena pada waktu itu Kalur sedang menghitung uang hasil copetannya. 
Data di atas dikatakan sebagai data dari tindak tutur ekspresif memuji karena adanya perasaan kagum atau takjub dari Yu Seblak sebagai penutur yang mengatakan kepada mitra tuturnya yaitu Kalur mengenai kehidupan Kalur yang beruntung.

Ajeng: em rayuan mas Karep ini sangat puistis, percintaan kita jadi dramatis.

Data kedua datang dari tokoh manusia yang bernama Ajeng. Pada saat itu Ajeng sedang bersama sang kekasih yaitu Karep. Adegan sebelumnya Karep sedang merayu Ajeng, sehingga muncul tuturan dari Ajeng berupa tindak tutur ekspresif memuji. Tuturan yang memiliki makna kekaguman atas apa yang dilakukan oleh mitra tutur yaitu Karep, membuat Ajeng tidak sengaja mengeluarkan tuturan tersebut.

Data di atas dapat disimpulkan sebagai tindak tutur ekspresif memuji karena Ajeng mengeluarkan suatu tuturan yang menyiratkan kekaguman atas apa yang mitra tutur tuturkan sebelumnya mengenai rayuan yang dikeluarkan.

\section{Tindak Tutur Ekspresif Menyanjung}

Tindak tutur ekspresif yang ketiga adalah menyanjung. Tindak tutur menyanjung adalah tuturan yang hadir berupa pujian akan tetapi memiliki tujuan lebih utama yaitu agar mitra tutur terbangun rasa senang di dalam hatinya.
Wibagso: kamu memang matamata yang cerdas, matamu setajam mata elang, pendengaranmu setajam kesunyian.

Data di atas merupakan data dari tindak tutur ekspresif jenis menyanjung. Dialog di atas dituturkan oleh tokoh monumen yang bernama Wibagso. Wibagso mengatakan tuturan yang berisi pujian agar lawan dialognya yang bernama Ratri senang. Bahkan pada dialog di atas terlihat bahwa Wibagso sangat pandai merangkai kata-kata dan dilihat dari mimik wajah dari Ratri, Wibagso berhasil menyanjungnya.

Data di atas dapat disimpulkan bahwa termasuk dalam tindak tutur ekspresif dengan jenis menyanjung. Karena tujuan tindak tutur ini adalah membangkitkan rasa senang di hati mitra tutur, dan Ratri terlihat senang dengan apa yang dikatakan oleh Wibagso. Maka benar data ini adalah dari tindak tutur ekspresif menyanjung.

\section{Tindak Tutur Deklaratif dalam Karya Seni Pertunjukkan Drama}

Jenis tindak tutur ilokusi yang kelima adalah tindak tutur deklaratif, tindak tutur deklaratif adalah tindak tutur yang apabila tuturan itu dituturkan akan adanya perubahan atau pengaruh tertentu pada suatu keadaan yang terjadi. Tindak tutur deklaratif yang terdapat pada karya seni pertunjukkan drama virtual dengan 
judul monumen ini memiliki dua jenis yaitu jenis memutuskan dan melarang.

\section{Tindak Tutur Deklaratif Memutuskan}

Jenis tindak tutur deklaratif yang pertama yaitu memutuskan, tindak tutur memutuskan adalah penutur akan membuat suatu keputusan mengenai keadaan tertentu.

Yu Seblak: ya sudah kita hadapi sendiri buldoser itu

Data pertama datang dari tuturan oleh tokoh manusia yang bernama Yu Seblak, pada adegan sebelumnya Yu Seblak mendapatkan laporan dari rekan-rekannya bahwa sudah tidak ada lagi manusia yang mau menolongnya untuk menghentikan penggusuran monumen yang mereka jadikan rumah mereka, sehingga munculah keputusan dari Yu Seblak dengan mengatakan bahwa kita yang akan menghadapi buldoser itu, dengan sangat yakin bahwa mereka bisa menghadapinya sendiri.

Data ini bisa dikatakan sebagai tindak tutur deklaratif karena pada kejadian ini terdapat perubahan keadaan yang awalnya Yu Seblak mempunyai inisiatif untuk mengumpulkan massa dalam melawan para buldoser, akan tetapi setelah mendapat laporan dari rekan-rekannya Yu Seblak mengambil keputusan akan melawan sendiri. Adanya perubahan keadaan sehingga data di atas layak disebut sebagai data dari tindak tutur deklaratif memutuskan

\section{Tindak Tutur Deklaratif Melarang}

Jenis kedua dari tindak tutur deklaratif adalah melarang, melarang adalah tindak tutur yang diujarkan oleh penutur dalam bentuk perintah untu tidak melakukan suatu hal atau kegiatan.

Wibagso: Jangan tergesa menyimpulkan dulu, rekan Durmo. Aku rasa mereka tetap hormat pada kita. Buktinya, mereka membangunkan monumen yang megah ini.

Data pertama dari jenis tindak tutur deklaratif melarang datang dari tokoh monumen yang bernama Wibagso, Wibagso menuturkan suatu larangan kepada Durmo, karena pada adegan sebelumnya Durmo menarik kesimpulan yang belum tentu kebenarannya bisa dipercaya, sehingga muncul larangan dari Wibagso, larangan berupa tidak tergesa dalam menarik kesimpulan yang buruk terhadap perilaku yang orang lain lakukan. Dan Wibagso juga meminta kepada Wibagso untuk menyadari bahwa beruntung dibangunkan monumen yang menurut Wibagso megah.

Data di atas bisa dikatakan dengan data melarang dengan bukti adanya kata [jangan]. Kata jangan merupakan kata yang menyatakan suatu larangan atau bisa diartikan dengan tidak memperbolehkan.

Kalur: halah, ga usah cringis nyah. 
Data kedua datang dari tokoh manusia yang bernama Kalur, pada saat itu Kalur sedang berdialog dengan Yu Seblak, yang kemudian Kalur merasa sudah tidak mau berdebat lagi dengan Yu Seblak akhirnya muncul dialog di atas. Frasa [ga usah] merupakan frasa tidak baku, sedangkan dalam bentuk bakunya adalah [tidak usah] data ini menjadi data dari tindak tutur deklaratif melarang karena terdapat partikel [tidak] yang memiliki makna sama dengan kata [jangan] yang berarti suatu larangan.

Yu Seblak: jangan hancurkan rumah kami

Data ketiga tentang tindak tutur deklaratif larangan datang dari dialog Yu Seblak pada adegan terakhir pada bagian manusia. Pada saat itu $\mathrm{Yu}$ Seblak sedang melawan buldoser untuk mempertahankan monumen yang hendak dihancurkan. Akan tetapi, pada saat itu rekan-rekannya sudah tidak berani maju, sehingga $\mathrm{Yu}$ Seblak sendiri melawan dengan mengayunkan senjata dan mengucapkan "jangan hancurkan rumah kami" pada dialog di atas terdapat kata kunci [jangan] yang memiliki makna larangan sehingga sudah benar data ini masuk dalam tindak tutur deklaratif melarang.

\section{SIMPULAN}

Tujuan dari penelitian ini adalah mendekripsikan tindak tutur ilokusi yang ada pada karya seni pertunjukkan drama virtual yang diadopsi dari naskah drama yang berjudul Monumen karya Indra Tranggono. Dengan hasil yang ditemukan yaitu tindak tutur ilokusi terdapat lima jenis: (1) tindak tutur asertif, berupa menyatakan, mengeluh, melaporkan, dan menunjukkan; (2) tidak tutur direktif, berupa jenis tindak tutur menyuruh, mengajak, meminta, menyarankan, menasihati, dan menantang; (3) tindak tutur komisif, berupa berjanji, menawarkan sesuatu, dan mengancam; (4) tindak tutur ekspresif berupa menyalahkan, memuji, dan menyanjung; dan (5) tindak tutur deklaratif berupa tindak tutur memutuskan dan melarang.

Tindak tutur yang ditemukan pada pementasan drama virtual oleh Teater Kandang semua tokoh ikut berperan aktif dalam menuturkan berbagai macam tuturan.

\section{REFERENSI}

Arifiany, N. \& Ratna, S. I. T. (2016). Pemaknaan Tindak Tutur Direktif Dalam Komik "Yowamushi Pedal Chapter 8793." Journal of Chemical Information and Modeling, 2(1), $1-11$.

Elmita, W., Ermanto, \& Ratna, E. (2013). Tindak Tutur Direktif Guru Dalam Proses Belajar Mengajar di TK Nusa Indah Banuaran Padang. Jurnal Pendidikan Bahasa Dan Sastra Indonesia, 1(2), 139-147.

Fadli, M. R. (2021). Memahami desain metode penelitian kualitatif. Humanika, 21(1), 33-54. https://doi.org/10.21831/hum.v2 
$1 \mathrm{i} 1.38075$

Fatonah, I., Samingin, F., \& Ekawati, M. (2018). Tindak Tutur Ilokusi Pada Spanduk Di Magelang. Riset Pendidikan Bahasa Dan Sastra Indonesia, 1(1), 56-67.

Megawati, E. (2016). Tindak Tutur Ilokusi Pada Ineraksi Jual Beli di Pasar Induk Kramat Jati. 08(02), 157-171.

Ni Nyoman Ayu Ari Apriastuti. (2017). Bentuk, Fungsi Dan Jenis Tindak Tutur Dalam Komunikasi Siswa Di Kelas Ix Unggulan Smp Pgri 3 Denpasar. Jurnal Ilmiah Pendidikan Dan Pembelajaran, 1(1), 38-47.

Praptiwi, R. E. (2020). Tindak Tutur Ilokusi Guru Pada Kegiatan Belajar Mengajar Di Smp Labschool Unesa Ketintang Surabaya. Bapala, 7(2), 1-10.

Purba, A. (2011). Tindak tutur dan peristiwa tutur. 1(1), 77-91.

Qomariyah, L. (2017). Tindak Tutur Direktif Guru Dalam Pembelajaran Bahasa Arab. Arabi: Journal of Arabic Studies, $2(1), \quad 1$. https://doi.org/10.24865/ajas.v2i 1.32

Rahma, A. N. (2018). Analisis tindak tutur ilokusi dalam dialog film animasi. 2(2), 13-24.

Sagita, V. R., \& Setiawan, T. (2020). Tindak Tutur Ilokusi Ridwan Kamil dalam "Talkshow Insight" di CNN Indonesia (The Form and Type of Illocutionary Speech Acts Ridwan Kamil in the "Insight Talkshow" at CNN Indonesia). Lensa: Kajian Kebahasaan, Kesusastraan, Dan Budaya, $\quad 9(2), \quad 187$. https://doi.org/10.26714/lensa.9.
2.2019.187-200

Siddiq, M. (2019). Tindak Tutur Dan Pemerolehan Pragmatik Pada Anak Usia Dini. KREDO : Jurnal Ilmiah Bahasa Dan Sastra, 2(2), 268-290.

https://doi.org/10.24176/kredo.v $2 \mathrm{i} 2.2868$

Stambo, R., \& Ramadhan, S. (2019). Tindak Tutur Ilokusi Pendakwah Dalam Program Damai Indonesiaku di TV One. Basindo, 3, 250-260.

Suryatin, E. (2018). Tindak Tutur Direktif Bahasa Indonesia pada Poster Kesehatan di Puskesmas Kota Banjarbaru. Undas, 14(1), 117-128.

Wahyuni, S. T., Retnowaty, \& Ratnawati, I. I. (2018). Tindak Tutur Ilokusi pada Capption Akun Islami di Instagram. 1(2), 11-18.

Yuliana, R., Rohmadi, M., \& Suhita, R. (2013). Daya Pragmatik Tindak Tutur Guru dalam Pembelajaran Bahasa Indonesia pada Siswa Sekolah Menengah Pertama. 2(April), 1-14. 